\title{
Public Movements in Formation of Rehabilitation Services for Youth and Children with Disability: Advantages and Risks
}

\author{
Ostrolutska Larysa \\ Methodist of Kyiv City Center for Social Services for the Family, \\ Children and Youth (Ukraine, Kyiv)
}

\begin{abstract}
In this paper successful examples of activities of public sector in formation of relevant rehabilitation services for children and youth with disability during the time of Ukraine`s independence are reviewed. Adaptation strategies of parents for children disability are analyzed: "normalization", "altruism", "crusade", "obedience". The criteria of social inclusion are determined. The stages of persons with disability "entering" to the social life: adaptation, socialization, integration, inclusion. As a result of research rehabilitation services of non-governmental organizations were reviewed: Charitable Society for Assistance to People with Disabilities as a result of Intellectual Disorders "Dzherela", Lviv Regional Parental Association for the Protection of Children with Cerebral Palsy "Nadiya", All-Ukrainian Association of Persons with Disabilities "Active Rehabilitation Group", All-Ukrainian Charity Organization "Down Syndrome", Non-Governmental Organization "Feel". Development of rehabilitation services for people with disabilities by public movements has its own advantages and risks. The perspective direction of research could be foreseen combination of studying the processes of society democratization and the role of public associations in services development for children and youth with disabilities.

Key words: rehabilitation services, non-governmental organizations for people with disability, inclusion, children and youth with disability, social pedagogy
\end{abstract}

Актуальність дослідження. На початку 1990-х рр у незалежній Україні почали зароджуватись рухи людей з інвалідністю щодо забезпечення своїх конституційних прав на якісне життя. Умовно ми можемо розділити громадські організації, які об'єднують людей 3 інвалідністю, на три групи: громадські організації (ГО) батьків дітей 3 інвалідністю; молодіжні громадські організації осіб 3 інвалідністю; громадські організації осіб з інвалідністю. Також ці організації можуть функціонувати на різних суспільно-територіальних рівнях, що позначається їхнім статусом, як то: місцеві, всеукраїнські, міжнародні ГО.

Розвиток і вплив громадських рухів осіб з інвалідністю на суспільне і політичне життя вивчалися вітчизняними науковцями, як-от Д. Козел (щодо захисту дітей 3 інвалідністю), Г. Хворовою (роль батьківських організацій в формуванні батьківських компетенцій), В. Мельник (становлення недержавного соціального захисту осіб 3 інвалідністю), М. Заболотною (участь громадських організацій молоді з інвалідністю у формуванні і реалізації державної політики). Натомість науковий аналіз показав, що роль громадських рухів у становленні реабілітаційних послуг для дітей та молоді 3 інвалідністю не отримав достатнього представлення у науковій літературі. Тому, цей 
аспект спонукав нас поставити питання про роль громадської активності добровільних об’єднань людей щодо розвитку та ствердження системи реабілітаційних послуг для осіб 3 інвалідністю.

Метою статі постало оприлюднення результатів пілотажного дослідження щодо ролі громадських рухів осіб з інвалідністю у напрямку розбудови реабілітаційних послуг для дітей та молоді з інвалідністю на різних рівнях соціального функціонування як на місцевому, всеукраїнському так і міжнародному.

Виклад основного матеріалу. У сучасному розумінні інвалідність розглядається як результат взаємодії, яка відбувається між людьми, які мають порушення здоров'я, i відносицькими та середовищними бар'єрами і яка заважає повній та ефективній участі в житті суспільства на рівні з іншими [2]. На час зародження громадського руху осіб 3 інвалідністю (90-ті pp XX ст.), інвалідність розглядалась як індивідуальна медична проблема з причини «недієздатності» особи. Наразі українське суспільство пройшло певну трансформацію з розуміння інвалідності: від медичної до соціальної, із соціальної до правової і біопсихосоціальної моделей, і розглядає інвалідність як різноманіття людського роду, яка потребує додаткових послуг, обладнання або інших ресурсів для задоволення своїх потреб бути членом суспільства і вести самостійне життя [6; 7; 9; 10; 16; 17]. Науковцями визнається, що ситуація інвалідності може привести людину до складних життєвих обставин (далі СЖО), однак сам факт інвалідності не можна тлумачити у категоріях СЖО.

Проведений українським науковцями у 2001 р. аналіз можливості в Україні влаштування дітей-сиріт з функціональними обмеженнями у замінні сім’ї вказав на громадську активність осіб, які зіткнулися із ситуацією потреби дитини з інвалідністю у замінному догляді. Описані ними факти підтримки дітей з інвалідністю вказали на умови, за яких підтримуючі особи могли розвивати свою активність у розбудові реабілітаційних послуг для осіб з інвалідністю [11, с. 56-77]. Із проведеного дослідження можна зробити припущення, що саме життя дитини з інвалідністю та іï причетність до іiі ситуації інвалідності може виступати критерієм тривалості активності дорослого щодо підтримки осіб з інвалідністю. Наразі питання влаштування дітей з інвалідністю у замінні сім’ї лише частково піднімаються в українських дослідженнях, як і рух щодо їх підтримки, що 
можна розглядати лише як перспективний напрямок розвитку соціальної політики [1, c. 77-96].

У контексті нашої роботи важливим внеском є дослідження американських вчених М. Селігмана та Р. Дарлінга. Вони вивчали рівні адаптації батьків щодо ситуації інвалідності дитини [5, с. 99]. У контексті розробленою ними шкали адаптації розглянемо стратегії батьків і громадських рухів осіб з інвалідністю до вирішення актуальних питань пов’язаних з інвалідністю (табл. 1).

Таблиця 1

Аналіз стратегій у контексті соціальних змін

\begin{tabular}{|l|l|l|}
\hline Стратегії адаптації & \multicolumn{1}{|c|}{ Дії } & \multicolumn{1}{c|}{ Типи залучення } \\
\hline «Нормалізація» & життя в суспільстві & $\begin{array}{l}\text { інклюзія; } \\
\text { інтеграція }\end{array}$ \\
\hline «Хрестовий похід» & $\begin{array}{l}\text { створення послуг; } \\
\text { зміни в суспільстві }\end{array}$ & $\begin{array}{l}\text { створення субкультури } \\
\text { субкультура, як тимчасове явище }\end{array}$ \\
\hline «Альтруїзм» & допомога іншим & $\begin{array}{l}\text { інклюзія } \\
\text { субкультура, як тимчасове явище }\end{array}$ \\
\hline «Покірність» & ізоляція & $\begin{array}{l}\text { задаптація, складні життєві } \\
\text { обставини }\end{array}$ \\
\hline
\end{tabular}

М. Селігман і Р. Дарлінг наголошували, що якісне залучення в суспільне життя досягають стратегії «Нормалізація» і «Альтруїзм». Натомість, стратегії типу «Хрестовий похід» і «Покірність» не можна охарактеризувати таким чином. При тому, що ці стратегії змінюються в залежності від потреб сімей, віку дитини, можливостей, рівня доступу до допомоги. Дослідники наголосили, що зазначена інформація допомагає зрозуміти стиль життя сім’ї, але іiї використання для стереотипізації сімей буде хибним кроком 3 посиленням тенденцій стигматизації та приписування ярликів. Натомість, на сучасному етапі видається доцільним доповнити уже зазначені типи залучення сімей реаліями сьогодення, як-то: інклюзія а також розділити поняття «субкультури», як явища, згідно часу його тривалості - тимчасова (стала).

Слід відмітити, що підхід «Нормалізація», який зародився в соціальній політиці Скандинавських країн у 60-х pp. XX ст. [14, с. 12], наголошує, що 1) у ситуації інвалідності людина може вести звичайний спосіб життя, як і решта людей, що включає: звичайний режим (робота і відпочинок, вільний час), 2) можливість планувати свій день і змінювати графік за бажанням чи потребою, 3) звичайний ритм тижня (робочі і вихідні 
дні); звичайний ритм року (свята і відпустки), 4) можливість переміщатися (жити в одному місці, а працювати в іншому), 5) звичайний розвиток життєвого циклу (дитинство, підлітковий вік, юність, зрілість, старість), 6) повагу і право до самовизначення, 7) стосунки, 8) звичайні для конкретної країни економічні права i можливості, 9) звичайні для конкретної країни вимоги до навколишнього середовища $\mathrm{i}$ житлових стандартів [5, с. 77]. Стратегія «Нормалізація» передбачає прийняття інвалідності всіма членами сім’ї і самою людини з інвалідністю (з врахуванням того, що кожний член сім’ї індивідуально проходить шлях прийняття в сенсовому і часовому вимірах), повернення до звичайного життєвого ритму всіх членів сім’ї (з урахуванням потреб члена сім'ї з інвалідністю), інклюзивне життя в суспільстві особи з інвалідністю.

Ще раз назвемо критерії соціального включення (інклюзіï), визначені Джудіт С. Райкус: 1) бути прийнятим і визнаним в якості особистості, 2) мати особисті взаємини 3 членами родини, друзями, знайомими, 3) бути включеним в дозвілля, відпочинок і інші суспільні заходи, 4) мати належне житло, 5) мати роботу, 6) мати формальну i неформальну підтримку. Зрозуміло, що така стратегія має на увазі створену систему підтримки осіб з інвалідністю і членів їх сімей, розвинуту сферу послуг і реабілітації, доступного середовища тощо. Водночас, на протилежній шкалі стратегії «Нормалізація» є стратегія «Покірність», яка ізолює сім’ю від суспільства, стигматизує інвалідність, знижує пошук підтримки і приводить до дезадаптації. Сім'я може не мати ресурсів підтримки з різних причині: відсутності послуг і організацій, бідність, низький рівень реабілітаційної культури, віддаленого проживання в тому числі. Члени сім’ї не беруть участь в громадських рухах із захисту прав осіб з інвалідністю, не мають спілкування 3 іншими сім'ями, які виховують дітей з інвалідністю. Така сім'я має ризик потрапити до складних життєвих обставин, знизити свій рівень якості життя, жити в стресі.

Стратегія «Хрестовий похід» об’єднує батьків дітей 3 інвалідністю чи осіб 3 інвалідністю для вирішення певних питань, захисту прав і змін у суспільстві пов’язаних 3 інвалідністю: створення послуг, медичне забезпечення, впровадження інклюзивної освіти, створення безбар'єрного середовища тощо. В разі створення необхідної системи підтримки переходять до стратегії «Нормалізація». Наш аналіз показав, що в умовах України ми спостерігаємо тенденцію «Хрестового походу» до вирішення певних питань, 
створення послуг для представників конкретної інвалідності (або вікової групи осіб 3 інвалідністю) і залишатися на цьому рівні не включаючись в життя всього суспільства.

Також було відмічено, що названі тенденції приводять до створення субкультури. Явище субкультури (національні, професійні, демографічні, географічні тощо) притаманне будь-якому суспільству, і є частиною нашої ідентичності, разом з тим і ми є частиною суспільства, а кожна субкультура має інтегруватися і посилювати загальну культуру суспільства. Субкультура може стати проблемою, коли замінює все суспільство і посилюється тенденції ізоляції засобом обмеження спілкування та взаємодії лише серед «своїх». Наше дослідження підтвердило, що субкультуру слід оцінювати як етап розвитку у напрямку інтеграції як один із кроків формування наступної ланки включення людей 3 інвалідністю у загальний соціальний процес. Наприклад, після розпаду Радянського Союзу випускники спеціальних шкіл-інтернатів (для дітей з інвалідністю) залишалися без професійного навчання і працевлаштування. Для вирішення цього питання у 1998 р. Благодійне товариство допомоги особам з інвалідністю внаслідок інтелектуальних порушень «Джерела» (м. Киї) створили програму «Випускник» (1997) для підготовки випускників інтернатних закладів до самостійного життя. 3 часом для них розробили програму «Трамплін» (1998), яка створювала умови для працевлаштування молоді зі зниженим інтелектом. 32000 року програма стала фінансуватись департаментом соціальної політики Київської міської державної адміністрації як спеціалізований центр [4]. Але, на жаль, для більшості відвідувачів центру програма не стала трампліном з працевлаштування, а залишила в цьому центрі до цього часу у якості субкультури, що домінуванням підтримуючої функції над розвивальною для іiі членів. Таким чином, ми спостерігаємо, що вирішення певного соціального питання осіб 3 інвалідністю може допомогти особам 3 інвалідністю адаптуватись через тимчасово створені умови і субкультуру, але може залишити їх в ній ізолюючі від суспільства.

Було встановлено, що стратегія «Альтруїзм» $\epsilon$ найменше розповсюджена в розвинутих країнах як стратегія адаптації сім’ї до ситуації інвалідності: після досягнення мети «Нормалізації», батьки знижують свою активність в діяльності організацій, участь в якій підкреслює стигматизуючий статус в суспільстві. Було встановлено, що розпочату активність продовжують лише ті батьки, які займали ведучі позиції на рівні регіональних і національних організацій. Зберегли свою позицію альтруїстів також і ті батьки, які 
вільно обирали цей тип адаптації для допомоги іншим батькам і ратували за просування змін. На нашу думку, в Україні, цей тип адаптації може мати два напрями: нормалізація/інклюзія/інтеграція або створення субкультури. При цьому створення субкультури може формуватися як етап на обраному шляху (тимчасова) задля підвищення адаптивних можливостей руху осіб з інвалідністю і членів їх сімей, переходу до нормалізації або як тенденція до відмежування та відчуження через створення самоізолюючої субкультури.

Українські дослідники О. Беспалько, І. Зверева, Г. Лактіонова, А. Капська вивчали базові дефініції соціальної педагогіки входження індивіда в суспільне життя, що супроводжується засвоєнням та відтворенням соціального досвіду. 3 урахуванням аналізу сучасної ситуації ми розглянемо етапи «входження» особи з інвалідністю в соціальне життя (табл. 2).

Таблиия 2

Етапи «входження» особи 3 інвалідністю в соціальне життя

\begin{tabular}{|c|c|c|c|c|}
\hline Eтап & Адаптація & Соціалізація & Інтеграція & Інклюзія \\
\hline 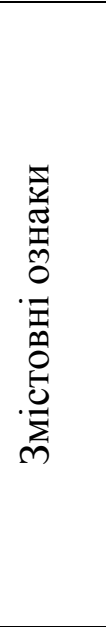 & $\begin{array}{l}\text { - види: } \\
\text { активна, } \\
\text { пасивна; } \\
\text { - етап } \\
\text { прийняття } \\
\text { інвалідності }\end{array}$ & $\begin{array}{l}\text { - види: стихійна, } \\
\text { відносно спрямована, } \\
\text { соціально- } \\
\text { контрольована; } \\
\text { - етапи: первинна, } \\
\text { вторинна; } \\
\text { - фактори: мікро-, мезо-, } \\
\text { мега-, макро-; } \\
\text { - соціально-педагогічні } \\
\text { механізми: традиційні, } \\
\text { інституціональні, } \\
\text { стилізовані, } \\
\text { міжособистісні }\end{array}$ & $\begin{array}{l}\text { - входження } \\
\text { існуючу } \\
\text { систему і } \\
\text { знаходження } \\
\text { свого місця; } \\
\text { - } \\
\text { підлаштування } \\
\text { під існуючі } \\
\text { норми і } \\
\text { цінності }\end{array}$ & $\begin{array}{l}\text { - нормалізація; } \\
\text { - соціальне } \\
\text { залучення; } \\
\text { - створення } \\
\text { власного простору; } \\
\text { - вплив на } \\
\text { суспільство; } \\
\text { - універсальний } \\
\text { дизайн послуг і } \\
\text { середовища }\end{array}$ \\
\hline
\end{tabular}

Таким чином, громадські організації осіб з інвалідністю можуть обрати шляхи для вирішення актуальних питань осіб з інвалідністю і залучення їх до життя в суспільстві через зміну нормативно-правового забезпечення, створення сервісних послуг, усунення соціальних бар'єрів, реалізації прав людей з інвалідністю тощо; всебічно сприяти нормалізації, самостійному життю осіб з інвалідністю, підвищенню якості життя, а також можуть створити субкультуру людей з інвалідністю, яка буде складатись із батьківських груп і ініціатив, регіональних громадських організацій, спеціалізованих мас-медія, регіональних і національних асоціацій осіб з інвалідністю [8]. 
Далі наведемо приклади діяльності громадських організацій щодо питань створення реабілітаційних послуг для осіб з інвалідністю.

У травні 1990 р. було створено Львівське обласне батьківське об'єднання захисту дітей з дитячим иеребральним паралічем «Надія», 31992 р. початок співпраці 3 волонтеркою 3 Канади 3. Кушпета, і спільно у 1993 р. створено «Навчальнореабілітащійний иеетр «Джерело». Ініціативу підтримали Львівська міська рада і департамент соціальної політики м. Львова.

Роботу розпочали з двох груп для дошкільнят, у 1994 р. було розпочато будівництво приміщення власного центру. За фінансової підтримки Українськоканадської програми «Партнери у сфері охорони здоров’я» у 1994-1995 рр. було створено навчальну програму підготовки спеціалістів фізичної реабілітації у Львівському державному інституті фізичної культури. В 1996 р. створена перша інклюзивна навчальна програма в поєднанні з реабілітацією в загальноосвітній школі № 82 (м. Львів). Роками пізніше було відкрито приміщення центру (2002) і розпочалась програма раннього втручання. На сьогодні центр надає реабілітаційні, соціальні, освітні послуги у відділеннях: садок-школа для дітей від 3-18 років (з важкими комбінованими формами інвалідності); відділення раннього втручання працює з дітьми від 4 років (має два філіали в дитячих поліклініках міста); відділення розвитку дитини (заняття 3 логопедом, психологом, фахівцем фізичної реабілітації, спеціальним педагогом); майстерні (денні реабілітаційні програми для осіб з інвалідністю старших 18 років). Центр має тренінговий центр і відділ соціальних проектів і розвитку. Щодня центр відвідує 200 вихованців [3].

Всеукраӥнське об’єднання осіб з інвалідністю «Група Активної Реабілітації» (ВГОI «ГАР») створена з метою здійснення заходів активної реабілітації осіб з травмами хребта і ураженням спинного мозку (які користуються кріслом колісним), самостійного життя, включення людей після травми хребта в усі аспекти життя. Організація діє в Україні з 1991 р., офіційно зареєстрована лише в 2002 р. У співпраці Із Шведською неурядовою організацією Рекрітерінгс Группен (Rekryteringsgruppen) українські активісти пройшли навчання методам активної реабілітації за методом «рівний-рівному». Активна реабілітація розглядається як комплекс заходів із застосуванням засобів фізичної культури і спорту, спрямованих на самообслуговування, максимальну незалежність у повсякденному житті і побуті, інтеграцію і громадську активність 
людини, яка перенесла травми або захворювання хребта і спинного мозку, і внаслідок цього пересувається на інвалідному візку. Основними складовими процесу активної реабілітації є фізична, психологічна та соціальна реабілітація. Організація здійснює три головні напрями: 1) проведення щорічних Таборів активної реабілітації, 2) перший контакт, 3) семінари фахівцям. Метою Табору активної реабілітації є досягнення людиною в колясці максимальної незалежності від сторонньої допомоги, і тим самим, поліпшення якості свого життя. Філософія табору грунтується на гаслі: «навчився жити в колясці сам - навчи іншого». Головну роль у процесі навчання грають інструктори в колясках, які мають психоемоційний вплив на учасників табору, оскільки є переконливим прикладом можливості вести повноцінне життя на рівні зі звичайними людьми. Методика проведення таборів активної реабілітації прийнята від Шведської неурядової організації Рекрітерінгс Группен (Rekryteringsgruppen). В Україні табори активної реабілітації проводяться з 1991 р. і реалізуються виключно ВГОІ «ГАР», за підтримки Українського центру «Інваспорт» 32002 р. і окремих благодійників. За роки діяльності табори реабілітували тисячу осіб з інвалідністю. Майже всі українські параолімпійські спортсмени і чемпіони свій спортивний шлях розпочали в таборах активної реабілітації.

Програма «Периий контакт»: створена для людей, які отримали травми спинного мозку і знаходяться в лікарні або реабілітаційному центрі. Перший контакт 3 інструкторами активної реабілітації надає людини після травми всебічної інформаційної підтримки, заохочення його до занять фізичними вправами і активного способу життя, попередження вторинних розладів і порушень. Інструктори першого контакту - це, в більшості випадків, люди, які перенесли такі ж травми хребта і спинного мозку і $є$ прикладом можливостей людей, які живуть в інвалідному візку, вміло ним володіють, самостійні у побуті і несуть теоретичні та практичні знання в сфері проблем і потреб людей після травм. Для розповсюдження досвіду і методу активної реабілітації ВГОІ «ГАР» проводяться семінари для працівників медичних закладів, які працюють 3 особами з травмами хребта (лікарі, реабілітологи, медсестри, інструктори ЛФК), а також з викладачами вищих навчальних закладів, які мають відношення до реабілітації. Мета навчань - показати потреби і можливості людини з травмою хребта і спинного мозку в пост лікарняний період [13]. 
Всеукраӥнська благодійна організаиія «Даун Синдром» заснована батьками дітей у 2004 p., а з 2010 р. є членом Європейської Асоціації Даун Синдром (European Down Syndrome Association). Громадська організація почала проводити активні просвітницькі кампанії з популяризації і розуміння осіб з синдромом Дауна (інформаційна кампанія 3 зірками культури та спорту України «Діти як діти, тільки 3 синдромом Дауна», організовано гастролі голандського Jostiband Orkest музикантів з інтелектуальною інвалідністю, започаткувала відзначання в Україні Дня осіб з синдромом Дауна 21 березня. В 2006 році започаткований проект із Київським департаментом охорони здоров'я Виконавчого органу КМДА та Київським центром соціальних служб для сім'ї, дітей та молоді з консультування породіль при народжені дитини з синдромом Дауна. Цей проект виявив національну прогалину з відсутності клінічного протоколу по синдрому Дауна для медиків, що часто приводило до того, що діти з синдромом Дауна не обстежували профільними фахівцями вчасно і багато проблем «списувалося» на наявність хромосомної аномалії. Сьогодні ВБО «Даун Синдром» реалізує проекти раннього втручання, освіти, працевлаштування дітей і молодих осіб з синдромом Дауна, надає підтримку батькам і сім'ям, має мережу організацій по Україні. Центр раннього розвитку надає професійні консультативно-педагогічні консультації дітям з синдромом Дауна від народження до 8 років. Проект організаиії - «Перспектива 21-3» має на меті створення перспективи для дітей з трисомією 21-ї хромосоми (синдром Дауна) та інших дітей з порушенням розумового розвитку в Україні у XXI столітті у трьох сферах життя: навчання, працевлаштування та самостійне проживання (з супроводом). Спільно зі спеціалізованою школою-інтернатом №26 (м. Київ), під науковим супроводом Національного інституту спеціальної педагогіки було розроблено новітні методики і впроваджені навчальні програми дітей із синдромом Дауна в освітнє середовище з 2011 p. Ці класи носять назву «Радість», в них навчається більше тридцяти учнів 3 різним спектром проблем розвитку від затримки психологічного розвитку до синдрому Дауна. В кожному класі навчається не більше 4х дітей з синдромом Дауна. 32017 р. організація реалізує проект «Підтримане пращевлаштування» 3 працевлаштування молодих осіб 3 синдромом Дауна в мережі магазинів «Ашан» [15].

Громадська організаиія «Відчуй» (м. Київ), заснована в 2011 р. з метою 
адаптації осіб $з$ порушенням слуху, реалізувала 15 всеукраїнських проектів, зарекомендувала себе серед сімей, які виховують дітей з порушенням слуху і спеціалістів різних спеціальностей. Протягом року організація надає реабілітаційні послуги дітям 3 порушенням слуху і підтримку сім'ям, в яких вони виховуються за такими напрямами: «Дитячий центр» (послуги з розвитку і корекції слухо-мовленєвої функції), «Клуб юніор» (психологічна підтримка, розвиток творчих здібностей, розвиток комунікаційних навичок для підлітків 38 до 12 років), «Підлітковий клуб Тееуs» (пошук друзів, підготовка до дорослого життя, клубні зустрічі, охоплює учасників 312 до 20 років) [12].

Висновки. Діяльність громадських організацій осіб з інвалідністю, як вираження потреб громадськості та прояв соціальної активності, є дієвою силою впливу на сучасну ситуацію щодо створення системи реабілітаційних послуг для осіб з інвалідністю впродовж їхнього життя. Встановлено, що критерієм, який може визначати термін включення громадських активістів у громадський рух, часто виступає тривалість життя особи з інвалідністю. Серед ризиків громадського сектору є 1) низький рівень розвитку демократичних процесів у самих організаціях, 2) низька активність осіб з інвалідністю в діяльності громадського сектору, 3) створення сталих субкультур осіб з інвалідністю без включення їх у суспільство, 4) фінансова залежність від грантів чи благодійників. Перевагами громадського сектору в розвитку реабілітаційних послуг $є$ розуміння актуальних потреб осіб з інвалідністю і дефіцитів послуг; створення нових сервісів для осіб з інвалідністю; залучення до співпраці міжнародних партнерів, науковців, державних організацій; довіра людей 3 інвалідністю і членів їх сімей; гнучкість і мобільність в плануванні своєї діяльності; публічне обговорення суспільних проблем.

Перспективним напрямком дослідження можна передбачити поєднання вивчення процесів демократизації суспільства і ролі громадських об’єднань щодо розвитку реабілітаційних послуг для дітей і молоді з інвалідністю.

\section{References}

1. Bevz H.M., Pesha I.V. Dytyna v pryiomni simi: notatky psykholoha [The child in foster care: notes from a psychologist]. Kyiv: Ukrainskyi in-t sotsialnykh doslidzhen, 2001. 101 p.

2. Konventsiia pro prava osib z invalidnistiu [Convention on the Rights of Persons with Disabilities]: Verkhovna Rada Ukrainy. 2006, Hrud. 13. URI: https://zakon.rada.gov.ua/laws/show/995_g71 
3. Istoriia Dzherela / sait Navchalno-reabilitatsiinoho tsentru «Dzherelo». URI : https://dzherelocentre.org.ua/istoriya-dzherela/

4. Istoriia stanovlennia / sait Blahodiinoho tovarystva dopomohy osobam $\mathrm{z}$ invalidnistiu vnaslidok intelektualnykh porushen «Dzherela». URI :

http://www.djerela.org/index.php/uk/pro-nas/istoriya-stvorennya

5. Obychnye semiy, osobye deti [Ordinary families, special children]: [per. s anhl.] / Selihman M., Darlynh R. Izd. 2-e. Moskva: Terevynf, 2009. 368 p.

6. Ostrolutska L.I. Sotsialna robota $z$ ditmy ta moloddiu $z$ invalidnistiu: mifi ta ukrainska realnist [Social work with children and youth with disabilities: myths and Ukrainian reality]. Pedahohichnyi Almanakh. 2012. No.16. P. 242-247.

7. Ostrolutska L I. Sotsialna robota $z$ ditmy ta moloddiu $z$ invalidnistiu: mify ta ukrainska realnist. Chastyna 2. [Social work with children and youth with disabilities: myths and Ukrainian reality. Part 2.]. Visnyk Kyivskoho natsionalnoho un-tu red imeni Tarasa Shevchenka «Sotsialna robota»: zb. nauk. pr. Kyiv. 2017. No. 2 (2). P. 16-19.

8. Ostrolutska L.I. Sotsialno-pedahohichni kompetentsii spetsialistiv sotsialnoi roboty $z$ ditmy ta moloddiu $z$ invalidnistiu ta yikh simiamy. [Social and pedagogical competencies of social work professionals with children and young people with disabilities and their families]. Visnyk Kyivskoho natsionalnoho universytetu imeni Tarasa Shevchenka "Sotsialna robota": zb. nauk. pr. Kyiv. 2017. No. 1 (1). P. 57-63.

9. Pet'ko L.V.English for students with specialization Psychology and Special Education”. Didactic material for practical classes and independent work of students in a foreign language specialties 6.010105 "Special Education", 6.030102 "Psychology", 6.030103 "Practical Psychology" : navch. posibnik dlya studentiv ta vykladachiv VNZ. Kyiv: Talkom, 2015. 160 p.

10. Petko L V. Realizatsiia kontseptsii pidhotovky mahistriv $v$ Ukraini dlia roboty $v$ inkliuzyvnomu osvitnomu prostori [The conception of the preparation masters' in Ukraine Implementation to work in an inclusive educational environment] // Aktualni problemy navchannia ta vykhovannia liudei v intehrovanomu osvitnomu seredovyshchi: Tr. KhI Mizhnar. nauk.-prakt. konf., lystopad 2011 r. Part I. Kyiv: VMURL «Ukraina». 2011. P. 92-94.

11. Pryiomni simi dlia ditei-syrit z funktsionalnymy obmezhenniamy [Foster families with orphans with functional limitations] / O.O.Yaremenko (kerivnyk avt. kol.) N.M. Komarova [ ta in.]. Kyiv : Ukrainskyi in-t sotsialnykh doslidzhen, 2001.120 p.

12. Pro nas / sait hromadskoi orhanizatsii «Vidchui».URI : https://vidchui.org/pro-nas/

13. Pro orhanizatsiiu [About organization] / sait Vseukrainskoho obiednannia osib z invalidnistiu «Hrupa Aktyvnoi Reabilitatsii». URI : https://gar.org.ua/about/

14. Put k rabote: Novyi vzghliad na reabylytatsyiu [The Road to Work: A New Look at Rehabilitation] / Per. so shvedsk. T. Antonchyk, L. Kopochel, O. Sochneva. - Minsk : UP «Tekhnoprynt», 2004. $256 \mathrm{p}$.

15. Tsentr rannoho rozvytku [The center of early development] / sait Vseukrainskoi blahodiinoi orhanizatsii «Daun Syndrom».

URI : http://downsyndrome.org.ua/centr-rannego-razvitiya 
16. Kusol Yevgen. Autism and a Child / Yevgen Kusol, Lyudmila Pet'ko // Materiály X mezinárodní vědecko - praktická konference «Věda a vznik - 2013/2014». - Díl 26. Psychologie a sociologie ; Šéfredaktor: Prof. JUDr Zdenĕk Černák. - Praha : Publishing House «Education and Science» S.r.o, 2014. S. 44-46.

17. Pet'ko Lyudmila. Braille System of Tactile Dots For Blind People / Lyudmila Pet'ko, Repetylo Elisabeth // Intellectual Archive, 2014. Vol. 3. No 2. Toronto : Shiny Word Corp. (Canada). P. 99-104.

Translation of the Title, Abstract and References to the Author's Language

\section{УДК 37.013.42+364.57+364.62}

Остролуцька Лариса. Громадські рухи щодо становлення реабілітаційних послуг для дітей та молоді з інвалідністю: переваги та ризики.

Розглянуто успішні приклади діяльності громадського сектору у створенні актуальних реабілітаційних послуг дітям та молоді 3 інвалідністю в Україні часів незалежності. Проаналізовано стратегії адаптації батьків до інвалідності дитини: «нормалізація», «альтруїзм», «хрестовий похід», «покірність» і визначені критерії соціального включення. Окреслено етапи «входження» особи з інвалідністю в соціальне життя: адаптація, соціалізація, інтеграція, інклюзія. Розглянуто реабілітаційні послуги громадських організацій: Благодійне товариство допомоги особам 3 інвалідністю внаслідок інтелектуальних порушень «Джерела», Львівське обласне батьківське об’єднання захисту дітей з дитячим церебральним паралічем «Надія», Всеукраїнське об’єднання осіб з інвалідністю «Група Активної Реабілітації», Всеукраїнська благодійна організація «Даун Синдром», Громадська організація «Відчуй».

Розбудова реабілітаційних послуг особам з інвалідністю громадськими рухами має свої визначені в статті переваги і ризики. Перспективним напрямком дослідження передбачено поєднання вивчення процесів демократизації суспільства і ролі громадських об’єднань щодо розвитку реабілітаційних послуг для дітей і молоді з інвалідністю.

Ключові слова: реабілітаційні послуги, громадські організації осіб з інвалідністю, інклюзія, діти та молодь з інвалідністю, соиіальна педагогіка.

\section{Остролуцкая Лариса. Общественные движения становления реабилитационных услуг для детей и молодежи с инвалидностью: преимущества и риски.}

Рассмотрены успешные примеры деятельности общественного сектора в создании актуальных реабилитационных услуг детям и молодежи с инвалидностью в Украине времен независимости. Изучены стратегии адаптации родителей к инвалидности ребенка: «нормализация», «альтруизм», «крестовый поход», «покорность» и определены критерии социального включения. Отмечены этапы «вхождения» человека с инвалидностью в социальную жизнь: адаптация, социализация, интеграция, инклюзия.

В результате исследования рассмотрены реабилитационные услуги общественных организаций: Благотворительное общество помощи лицам с инвалидностью вследствие интеллектуальных нарушений «Джерела», Львовское областное родительское объединение защиты детей с детским церебральным параличом «Надежда», Всеукраинское объединение лиц с инвалидностью «Группа активной 
реабилитации», Всеукраинская благотворительная организация «Даун Синдром», Общественная организация «Відчуй».

Развитие реабилитационных услуг лицам с инвалидностью общественными движениями имеет свои определённые в статье преимущества и риски. Перспективным направлением исследования можно предположить сочетание изучения процессов демократизации общества и роли общественных объединений по развитию реабилитационных услуг для детей и молодежи с инвалидностью.

Ключевые слова: реабилитационные услуги, общественные организации лии с инвалидностью, инклюзия, дети и молодежь с инвалидностью, сочиальная педагогика.

\section{Література}

1. Бевз Г. М., Пеша I. В. Дитина в прийомні сім’ї: нотатки психолога. Київ : Український ін-т соціальних досліджень, 2001. 101 с.

2. Конвенція про права осіб з інвалідністю: Верховна Рада України. 2006. Груд. 13. URI : https://zakon.rada.gov.ua/laws/show/995_g71

3. Історія Джерела [Електронний сайт] / сайт Навчально-реабілітаційного центру «Джерело». URI : https://dzherelocentre.org.ua/istoriya-dzherela/

4. Історія становлення / сайт Благодійного товариства допомоги особам 3 інвалідністю внаслідок інтелектуальних порушень «дерела». URI : http://www.djerela.org/index.php/uk/pro-nas/istoriya-stvorennya

5. Обычные семьи, особые дети: [пер. с англ.] / Селігман М., Дарлинг Р. Изд. 2-е. Москва : Теревинф, 2009. 368 с.

6. Остролуцька Л. І. Соціальна робота з дітьми та молоддю з інвалідністю: міфі та украӥнська реальність. Педагогічний Альманах. 2012. № 16. С. 242-247.

7. Остролуцька Л. І. Соціальна робота з дітьми та молоддю з інвалідністю: міфи та українська реальність. Частина 2. Вісник Київського національного ун-ту імені Тараса Шевченка «Сочіальна робота» : зб. наук. пр. 2017. № 2 (2). С. 16-19.

8. Остролуцька Л. І. Соціально-педагогічні компетенції спеціалістів соціальної роботи з дітьми та молоддю з інвалідністю та їх сім’ями. Вісник Київського національного університету імені Тараса Шевченка «Сочіальна робота» : зб. наук. пр. Київ, 2017. № 1 (1). C. 57-63.

9. Петько Л.В. Англійська мова для студентів-психологів та дефектологів. Дидактичний матеріал для практичних занять та самостійної роботи студентів 3 іноземної мови зі спеціальностей: 6.010105 «Корекційна освіта (за нозологіями)», 6.030102 «Психологія», 6.030103 «Практична психологія»: навч. посібник для студентів, магістрантів, аспірантів. Київ: Талком, 2015. 160 с.

10. Петько Л В. Реалізація концепції підготовки магістрів в Україні для роботи в інклюзивному освітньому просторі // Актуальні проблеми навчання та виховання людей в інтегрованому освітньому середовищі: Тр. ХІ Міжнар. наук.-практ. конф., листопад 2011 р. Ч. І. Київ: ВМУРЛ «Україна». 2011. С. 92-94. 
11. Прийомні сім'ї для дітей-сиріт з функціональними обмеженнями / О. О. Яременко (керівник авт. кол.) Н. М. Комарова, Р. Я. Левін та ін. Київ : Український ін-т соціальних досліджень, 2001. 120 с.

12. Про нас / сайт громадської організації «Відчуй» URI : https://vidchui.org/pro-nas/

13. Про організацію / сайт Всеукраїнського об’єднання осіб з інвалідністю «Група Активної Реабілітації». URI : https://gar.org.ua/about/

14. Путь к работе: новый взгляд на реабилитацию / Пер. со шведск. Т. Антончик, Л. Копочель, О. Сочнева. Мінськ : УП «Технопринт», 2004. 256 с., ил.

15. Центр раннього розвитку / сайт Всеукраїнської благодійної організації «Даун Синдром». URI : http://downsyndrome.org.ua/centr-rannego-razvitiya

16. Kusol Yevgen. Autism and a Child / Yevgen Kusol, Lyudmila Pet'ko // Materiály X mezinárodní vědecko - praktická konference «Věda a vznik - 2013/2014». - Díl 26. Psychologie a sociologie ; Š́fredaktor: Prof. JUDr Zdeněk Černák. - Praha : Publishing House «Education and Science» s.r.o, 2014. S. 44-46.

17. Pet'ko Lyudmila. Braille System of Tactile Dots For Blind People / Lyudmila Pet'ko, Repetylo Elisabeth // Intellectual Archive, 2014. Volume 3. Number 2. Toronto : Shiny Word Corp. (Canada). P. 99-104. 